\title{
INSTAGRAM SEBAGAI MEDIA GOVERNMENT \\ PUBLIC RELATIONS KEMENTERIAN \\ KOMUNIKASI DAN INFORMATIKA \\ DI MASA PANDEMI COVID 19
}

\author{
${ }^{1}$ Andrea Amorita Tulung, ${ }^{2}$ Sri Ulya Suskarwati, ${ }^{3}$ Virgin Cansa Abinta \\ 1,2,3 Institut Komunikasi dan Bisnis LSPR Post Graduate Programme \\ sri.us@1spr.edu
}

Diterima : 08 Desember 2020; Review : 03 Januari 2021; Direvisi Author : 20 Januari 2021; Terbit : 14 Februari 2021

\begin{abstract}
Since the spread of Covid-19 and declared a pandemic in Indonesia, the Government has provided various communication media as channels of information for the public. Instagram @ kemenkominfo is an official account managed by the Ministry of Communications and Informatics (Kemenkominfo), which is one of the information centers about Covid-19 in Indonesia and is a new medium for it's Government Public Relations (GPR) during the Pandemic. This study aims to understand the concept of GPR Kemenkominfo through Instagram, by referring to the theory of Computer Mediated Communication (CMC) to understand the virtual communication process between government and public. A qualitative descriptive approach with a case study method is used by researcher to achieve research objectives. The results of the study is understanding of the range, speed, and amount of information on @ kemenkominfo to provide knowledge and information according to public needs. Through Instagram, it provides understanding and direction regarding Covid-19 to public, as well as providing information dissemination services through an official account managed by Public Relations of the Ministry of Communications and Informatics. As a communicator and mediator in the spread of Covid-19 in Indonesia is the application of GPR concept during a pandemic. The Ministry of Communications and Informatics builds a conducive communication with the Indonesian people through the official Instagram account @ kemenkominfo.
\end{abstract}

Keyword:Government Public Relations, Instagram, Kemenkominfo, Computer Mediated Communicatio

\section{PENDAHULUAN}

Kasus covid-19 di Indonesia pertama kali diumumkan tanggal 2 Maret 2020 oleh Presiden RI Joko Widodo di Istana Merdeka, ketika pertama kali seorang ibu warga Depok tertular virus tersebut dari warga negara Jepang. Seperti dilansir pada linimasa detik.com, langkah pertama yang dilakukan pemerintah adalah membentuk Gugus Tugas Percepatan Penanganan covid-19 melalui Keputusan Presiden nomor 7 Tahun 2020. Selain itu pemerintah membuat berbagai kebijakan, antara lain menetapkan status darurat kesehatan masyarakat, Pembatasan Sosial 
Berskala Besar (PSBB), mengubah wisma atlet menjadi rumah sakit rujukan penanganan pasien covid-19, dan sebagainya (Detikcom, 2020).

Pemerintah menyediakan berbagai saluran informasi terkait Covid-19, agar masyarakat tidak panik, mendapatkan informasi yang benar, dan dapat memantau kasus tersebut. Salah satu media yang dimanfaatkan oleh pemerintah untuk mendistribusikan informasi di masa pandemi adalah media sosial Instagram, yaitu akun Instagram @kemenkominfo. Akun resmi yang dikelola oleh Kementerian Komunikasi dan Informatika (Kemenkominfo) ini menjadi salah satu pusat informasi mengenai Covid-19 di Indonesia, dan memiliki 1.7 juta followers (sumber: Instagram @kemenkominfo, 2021).

Instagram menjadi salah satu platform utama bagi Kemenkominfo untuk memberikan informasi, karena jumlah pengguna media baru ini semakin meningkat.

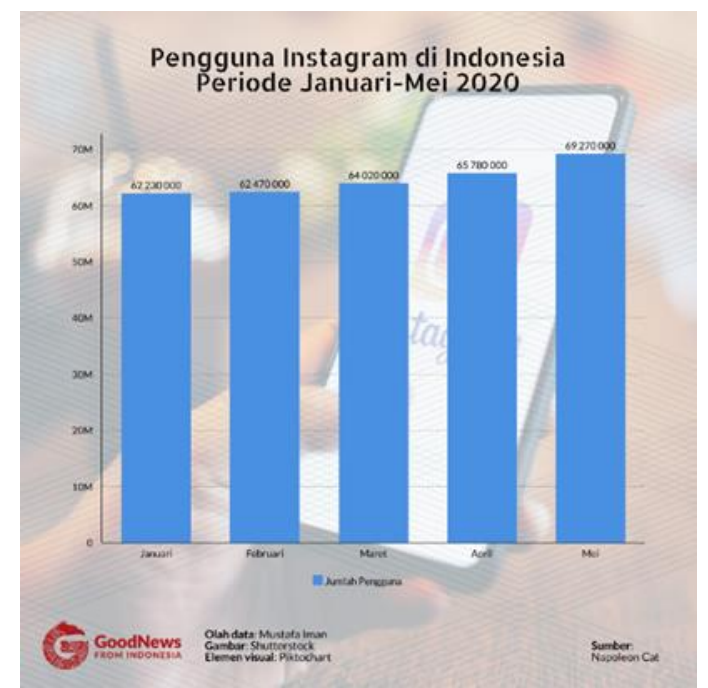
Gambar 1. Data Pengguna Instagram di
Indonesia, Januari-Mei 2020

Sumber:(Mustafa, 2020)

Dari datagambar 1 diketahui bahwa pengguna Instagram di Indonesia setiap bulannya terus meningkat. Dalam kurun waktu lima bulan terjadi peningkatan pengguna Instagram sebanyak tujuh juta akun. Instagram menjadi salah satu pilihan media sosial bagi masyarakat secara luas. Para pengguna Instagram memilih akun yang ingin diikuti, untuk mendapatkan informasi, hiburan, berbagi cerita, video/foto, dan lain-lain.

Instagram juga telah dimanfaatkan oleh pemerintah untuk melakukan kampanye sosial dalam rangka pencegahan Covid-19. Konten Instagram dirancang dengan baik, sehingga mampu menarik pengguna untuk mengakses konten (Situmeang, 2020). Konten Instagram yang 
menarik ini membuat kampanye sosial berhasil dengan baik.

Diketahui bahwa akun Instagram @kemenkominfo dan@kemenkes-ri di masa pandemi secara otomatis muncul pada fitur pencarian di Instagram. Hal ini menurut pengamatan peneliti menunjukkan bahwa pihak pemerintahan secara khusus menyediakan media komunikasi. Tujuannya, agar masyarakat Indonesia dapat mengakses dan mengetahui update informasi terkait Covid-19 dari akun resmi dengan logo centang biru (verified account). Kemenkominfo dan Kementerian Kesehatan sebagai pengelola akun Instagram @kemenkes-ri, menjadi pusat informasi selama masa pandemi.

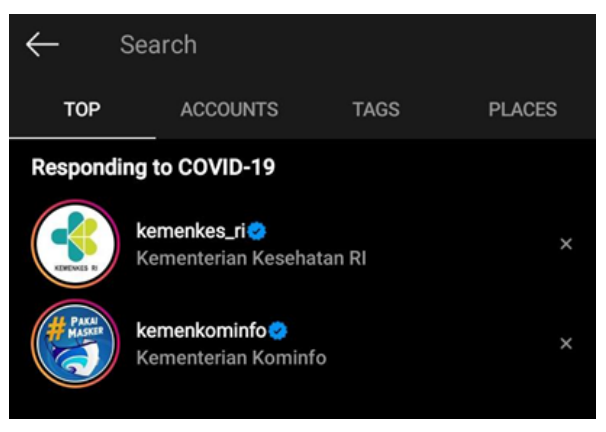

\section{Gambar 2. Top Search Instagram Sejak} Pandemi di Indonesia

(sumber: Instagram @kemenkominfo, 2020)

Kemenkominfo sebagai aparatur pemerintah yang berperan dalam bidang komunikasi dan informasi, berupaya menyediakan informasi terkini serta edukatif bagi masyarakat di tengah pandemi yang terjadi.

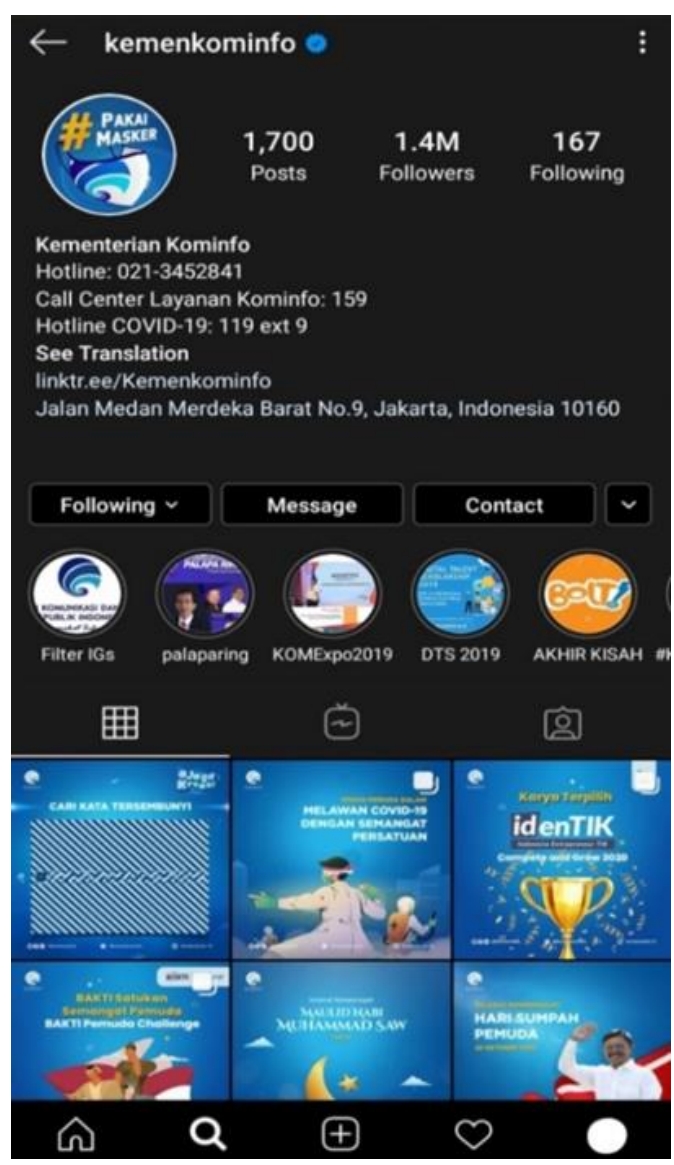

Gambar 3. Profil Akun Instagram @ kemenkominfo

(sumber: Instagram @kemenkominfo, 2020)

Pada gambar 3 terlihat profil akun Instagram@kemenkominfo berisi berbagai informasi, dan unggahan utama yaitu mengenai Covid-19. Tampak foto profil masker dengan logo Kemenkominfo, dan penggunaan tanda pagar (tagar) \#PAKAIMASKER. Profil ini tampak sebagai ajakan atau pesan yang ingin 
disampaikan oleh Kemenkominfo kepada masyarakat untuk menggunakan masker. Foto profil adalah hal pertama yang akan terlihat saat pengguna membuka kolom pencarian di Instagram.

Di masa pandemi, berbagai bentuk komunikasi kesehatan dibangun sebagai upaya untuk mencegah penyebaran virus yang masif ini. Aplikasi pelacak Covid-19 yang bernama 'PeduliLindungi' menjadi media komunikasi kesehatan antara pemerintah dan masyarakat. Aplikasi ini memberikan informasi kesehatan dan protokoler menghadapi pandemi Covid-19. Dengan mengaktifkan aplikasi, pengguna ikut serta dalam gerakan sosial dalam membangun kesadaran dan advokasi penggunaan internet sebagai sumber berita sebagai kontrol informasi (Kencana, 2020).

Media komunikasi dengan platform internet menjadi media informasi yang paling mudah diakses di masa pandemi ini, termasuk Instagram yang dimanfaatkan oleh Kemenkominfo. Pada tampilan Instagram @kemenkominfo ini, terdapat juga nomor hotline Covid-19 agar memudahkan akses informasi. Berdasarkan pengamatan peneliti, Instastory dan unggahandi akun@kemenkominfo juga memberikan informasi dan edukasi mengenai Covid-19 secara interaktif.
Dalam pelaksanaan publikasi di @ kemenkominfo banyak fitur-fitur yang digunakan sebagai media informasi dan interaksi antara Kemenkominfo dengan masyarakat.

Instagram sebagai media informasi dan wadah interaksi dengan masyarakat di masa pandemi, peneliti asumsikan sebagai aplikasi dari konsep Government Public Relations (GPR) dari Kemenkominfo. GPR atau Humas Pemerintah berfokus pada layanan public services yang dapat digunakan untuk meningkatkan kinerja dari pelayanan umum. Melalui unit Humas atau program kerja Humas, pemerintah dapat menyampaikan informasi atau menjelaskan mengenai kebijakan atau peraturan dan tindakan-tindakan serta aktivitas dalam melaksanakan tugas dan kewajiban dari organisasi pemerintah (Ruslan, 2010).

Akun@kemenkominfo juga berkolaborasi dengan akun resmi lainnya dalam menanggulangi dan memberi informasi serta edukasi. Seperti akun @lawancovid19_id, @indonesiabaik.id, @kemenkes-ri dan akun-akun resmi lainnya. Semua unggahan yang berkaitan dengan Covid-19 pada akun @ kemenkominfo, diberi tagar yang relevan dengan konten terkait Covid-19 agar memudahkan pengguna Instagram mencari 
dan menemukan informasi yang dibutuhkan.

Instagram sebagai media baru yang dimanfaatkan oleh Kemenkominfo dalam konsep GPR di masa pandemi, menarik untuk diteliti. Fungsi Instagram ini tentunya untuk memberikan informasi dan sebagai upaya edukasi bagi masyarakat terkait Covid-19 di Indonesia.

Ciri dari media baru adalah dapat diubah seiring berkembangnya teknologi, bersifat jaringan, padat, interaktif dan bersifat user generated content (UGC). UGC diartikan bahwa semua orang dapat menulis atau mengunggah konten ke internet (Solomon, 2011). Media baru juga diharapkan dapat berkontribusi dalam memberi kemajuan informasi, kesempatan belajar untuk semakin menjadi kreatif yang terbuka dan sifat komunikasi yang horizontal dan merata (Lister et al., 2009).

Selanjutnya, keberadaan Humas dalam sebuah lembaga atau instansi pemerintah secara fungsi merupakan keharusan guna penyebarluasan informasi dan publikasi mengenai aktivitas instansi terkait yang ditujukan untuk pihak internal maupun eksternal instansi. Humas adalah sarana atau saluran yang diartikan sebagai The PR as tools or channels of government publication. Kegunaannya adalah memberi kelancaran interaksi dan penyebaran informasi dan publikasi pembangunan nasional dengan kerjasama pihak pers, media cetak, media elektronik dan juga media tradisional lainnya (Ruslan, 2010).

Adapun fungsi pokok Humas Pemerintah di Indonesia antara lain: (a) Menjaga kebijaksanaan pemerintah. (b) Memberikan layanan dan peyebaran informasi mengenai kebijaksanaan program kerja instansi dengan jangkauan nasional kepada masyarakat. (c) Menjadi komunikator sekaligus mediator bagi pemerintah dan publik dalam menjembatani kepentingan instansi disatu pihak, dan menampung aspirasi publik, serta memperhatikan keinginan-keinginan publiknya dilain pihak. (d) Berperan menciptakan iklim komunikasi yang kondusif dan dinamis guna mengamankan stabilitas dan keamanan politik pembangunan nasional, baik berjangka pendek maupun Panjang (Ruslan, 2010).

Instagram @kemenkominfo yang digunakan sebagai $P R$ as tools or channels of government publication oleh Kemenkominfo sejak pandemi di Indonesia, merupakan media informasi dan penyebaran informasi kepada masyarakat.

Instagram merupakan salah satu bentuk dari media sosial. Media sosial 
adalah alat bantu dalam menyampaikan informasi dari satu orang ke orang lainnya atau kelompok, untuk mencapai tujuan individu maupun tujuan kelompok (Nasrullah, 2015). Manfaat menggunakan Instagram, selain untuk menyampaikan informasi kepada orang lain, juga dapat menjalin hubungan personal dengan followers, dan dapat membentuk citra organisasi atau perusahaan (Rubiyanto \& Yuliani, 2020).

Menurut Van Dijk (2013) media sosial adalah sebuah platform media yang fokus pada eksistensi pengguna untuk memfasilitasi mereka dalam beraktivitas maupun berkolaborasi. Media sosial dapat dilihat sebagai medium atau instrumen online yang menguatkan hubungan antar penggunanya sekaligus sebagai sebuah ikatan sosial antar satu dan lainnya (Nasrullah, 2015).

Penggunaan Instagram pada akun @kemenkominfo di masa pandemi, menjadi alternatif saluran komunikasi antara pemerintah dan masyarakat Indonesia yang mumpuni. Hal ini merupakan kepatuhan atas protokol kesehatan dalam upaya menekan penyebaran Covid-19. Instagram sebagai media komunikasi Kemenkominfo di masa pandemi ini, peneliti akan pahami dengan panduan teori Computer Mediated Communication (CMC).

CMC adalah proses komunikasi yang bersifat virtual menggunakan media komputer tanpa kontak fisik sehingga dapat mengurangi hubungan interpersonal. CMC juga dijadikan sebagai suatu alih teknologi komunikasi sebagai media dalam mengolah pesan atau ide dan informasi yang sudah jelas kebenarannya (Darmawan, 2012).

Selanjutnya dikatakan, CMC terbagi menjadi beberapa dimensi (Darmawan, 2012), yaitu: (a) Dimensi Accessibility (Daya Jangkauan / Akses). Dalam dimensi aksesibilitas, adalah indikasi akan jangkauan yang diraih dan tercapai dalam sebuah proses penyampaian informasi melalui proses CMC yang sangat luas. (b) Dimensi Speed (Kecepatan Informasi). Dimensi kecepatan dapat di indikasi dari proses penyampaian pesan oleh pengirim kepada penerima, hal ini menunjukan bahwa CMC dapat menyampaikan pesan dengan cepat. (c) Dimensi Amount (Jumlah Informasi). Dimensi amount menunjukan informasi yang disampaikan dari pengirim pesan kepada penerima pesan melalui CMC dapat memenuhi kebutuhan jumlah informasi yang dibutuhkan. 
Dimensi lainnya adalah: (d) Dimensi Cognitive Effectiveness (Keefektifan). Dimensi ini merupakan informasi yang di sampaikan pengirim pesan terhadap penerima pesan melalui CMC yang mampu memberi dan menambahkan pengetahuan dan informasi secara efektif sesuai kebutuhan. (e) Dimensi Relevansi (Kesesuaian Informasi). Dimensi ini menunjukan dimana informasi yang disampaikan pengirim pesan terhadap penerima pesan melalui CMC mampu menyesuaikan dengan kebutuhan terkait dari isi pesannya. (f) Dimensi Motivating (Motivasi). Dimensi motivating dimana informasi dari pengirim pesan kepada penerima pesan melalui CMC mampu memberikan motivasi untuk memahami dan menerapkannya dari isi pesannya.

Berdasarkan uraian yang telah dipaparkan, maka peneliti tertarik untuk mengkaji lebih lanjut bagaimana Instagram dimanfaatkan oleh Kementerian Komunikasi dan Informatika di masa pandemi Covid-19? Adapun tujuan penelitian untuk memahami pemanfaatan Instagram @ kemenkominfo sebagai media komunikasi di masa Pandemi Covid-19.

\section{METODOLOGI PENELITIAN}

Penelitian ini menggunakan pendekatan deskriptif kualitatif.
Pendekatan deskriptif kualitatif adalah sebuah penelitian untuk mengungkap sebuah fakta empiris secara objektif ilmiah dengan landasan logika keilmuan, prosedur dan dukungan dari teori dan metodologi yang kuat sesuai disiplin keilmuan yang diambil (Mukhtar \& Pd, 2013). Kebenaran suatu teori tersebut menawarkan berbagai perspektif "kebenaran" dari suatu realitas tetapi bukan satu-satunya cara untuk memandang suatu realitas atau fenomena (Rorong, 2019). Fenomena yang diamati dalam kajian ini, yaitu penggunaan Instagram sebagai sarana komunikasi publik di masa pandemi Covid-19.

Objek penelitian berfokus pada akun resmi Instagram @ kemenkominfo yang dikelola oleh Kemenkominfo, melalui metode studi kasus. Menurut Stake (1995) studikasus merupakan strategi penelitian di mana di dalamnya peneliti menyelidiki secara cermat suatu program, peristiwa, aktivitas, proses, atau sekelompok individu (Creswell, 2010). Adapun studi kasus yang dipakai peneliti, yaitu intrinsic case study (Denzin \& Lincoln, 2009), untuk memahami lebih baik penggunaan Instagram sebagai media informasi dan upaya edukasi Covid 19 bagi masyarakat Indonesia. 
Data primer dalam penelitian ini melalui pengamatan akun Instagram @ kemenkominfo, dan data sekunder diperoleh melalui wawancara dengan pihak internal Kemenkominfo yaitu: (1) Annissa Bonita, Sub. Koordinator Media Online Biro Humas dan Pranata Humas Ahli Muda Kementerian Kominfo. (2) Fernandius Setu, Plt. Kepala Biro Humas Kemenkominfo. Selain itu, data juga dihimpun melalui wawancara dengan pihak eksternal atau masyarakat yang mengikuti perkembangan pemberitaan Covid-19 melalui akun Instagram @kemenkominfo, yaitu (3) Rivandy Prakasa, karyawan swasta dan (4) Lilis Sumiarsih Ibu Rumah Tangga sebagai follower serta (5) Azura Fianda sebagai non follower, yang berprofesi sebagai konsultan pariwisata di Jakarta. Selain itu, data sekunder lainnya seperti pemberitaan media online peneliti gunakan untuk kebutuhan analisis sesuai dengan tujuan penelitian.

Alur analisis, peneliti rangkai dengan terlebih dahulu mengolah data berdasarkan panduan enam dimensi dalam teori Computer Mediated Communication (CMC). Analisis berikutnya, peneliti bangun untuk memahami relevansi objek penelitian dalam konsep Government Public Relations.

\section{HASIL DAN PEMBAHASAN}

Penyebaran Covid-19 yang berdampak pada seluruh aspek kehidupan masyarakat dunia dan salah satunya Indonesia, menyebabkan kebutuhan informasi terkait Covid-19 menjadi penting bagi masyarakat. Kemenkominfo merupakan Lembaga Pemerintah yang hadir untuk secara aktif melakukan penyebaran informasi seputar Covid-19. Melalui akun resmi @kemenkominfo yang dikelola oleh tim Biro Humas Kemenkominfo, menjadi media komunikasi antara pemerintah dan masyarakat.

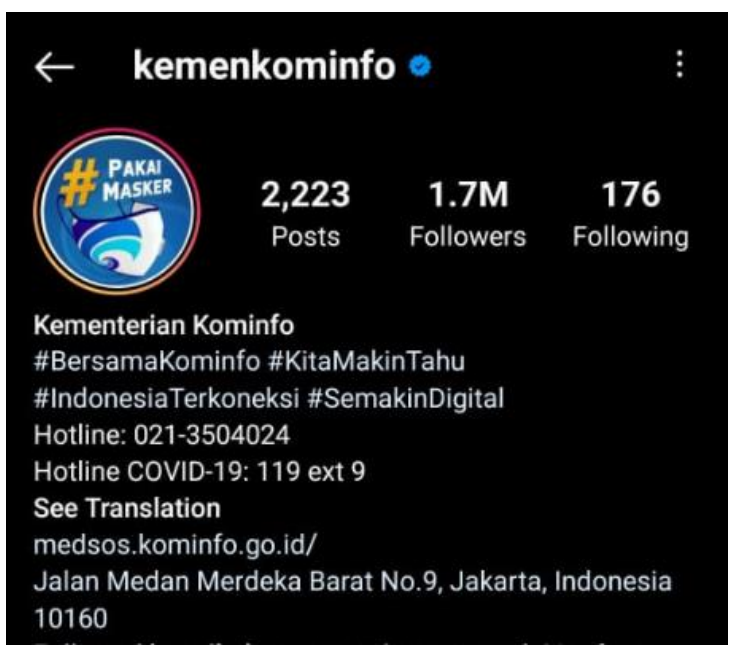

\section{Gambar 4. Profil Akun Instagram @ kemenkominfo}

(sumber: Instagram @ kemenkominfo, 2021) 
Berdasarkan gambar 4 tersebut, dapat dilihat bahwa jumlah followers Instagram berjumlah 1.7 juta orang ditahun 2021. Terjadi peningkatan jumlah follower sekitar orang 3 juta orang, di antara sebelum dan sesudah dilakukan penelitian. Bahkan menurut Fernandius Setu, sebelum terjadinya pandemi Covid-19 sekitar 500 700 ribu followers Instagram @ kemenkominfo (Setu, 2020).

Tidak hanya itu, menurut Setu (2020) tampilan Instagram harus menarik dengan layout yang kreatif, bagus, dan up to date. Instagram Kemekominfo ini bersama Instagram Kemenkes menjadi dua akun yang dipromosikan untuk selalu muncul paling atas dalam Instagram Indonesia.

Hal ini dipertegas oleh Annissa Bonita, bahwa setiap hari setidaknya ada satu hingga dua konten seputar Covid-19 yang diunggah ke akun Instagram @ kemenkominfo. Melalui konten yang disajikan secara aktif, pengemasan kreatif yang mudah dipahami, dan up to date, menjadi salah satu faktor Instagram mempromosikan akun@kemenkominfo dengan memunculkan akun tersebut ke dalam search engine Instagram Indonesia bersama dengan akun Instagram Kementerian Kesehatan (Bonita, 2020).
Seperti terlihat pada Instastory di akun @ kemenkominfo, menginformasikan kepada followers tentang prosedur mendapatkan vaksin, sebagi berikut:

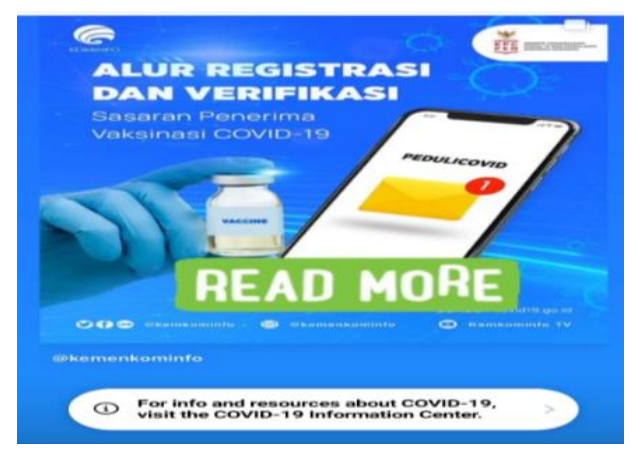

Gambar 5. Instastory @ kemenkominfo (sumber: Instagram @ kemenkominfo, 2021)

Tidak hanya followers Instagram @kemenkominfo saja yang mengalami peningkatan, namun engagement akun ini juga ikut meningkat dibandingkan sebelum pandemi Covid-19 menyebar di Indonesia. Hal ini menunjukkan bahwa banyak pengguna Instagram yang membutuhkan informasi dan data mengenai Covid-19. Akun ini biasanya hanya mencapai ratusan ribu impression atau satu juta impression sebulan. Namun semenjak pandemi, meningkat menjadi minimal satu atau dua juta impression sebulan (Setu, 2020).

Peningkatan followers dan engagement dapat dilihat juga dari respon masyarakat yang membutuhkan informasi terkait Covid-19. Mulai dari masyarakat 
non-follower yang terus mengikuti dan memantau berita Covid-19 dari search engine otomatis akun instagram @ kemenkominfo, serta masyarakat yang menjadi followers baru akun instagram @ kemenkominfo karena ingin mengikuti bagaimana informasi perkembangan Covid-19.

Salah satu follower akun Instagram @ kemenkominfo yang merupakan pengikut baru, yaitu Rivandy Prakasa mengakui bahwa dirinya telah menjadi followers@kemenkominfo kurang lebih selama setahun ini saat dimulainya pandemi di tahun 2020 (Prakasa, 2020). Selaku follower akun Instagram @ kemenkominfo, Rivandy merasa terpenuhi kebutuhannya untuk mengetahui informasi mengenai Covid-19. Selain kebutuhan akan informasi terpenuhi sebagai followers, ia juga merasa bahwa akun resmi ini terjaga kredibilitasnya karena dikelola oleh pemerintah.

Selain manfaat yang dirasakan followers akun Instagram @ kemenkominfo dalam memperoleh informasi terkait Covid-19, pemaparan informasi mengenai Covid-19 juga memberikan manfaat terhadap non-followers akun Instagram @ kemenkominfo. Pasalnya kemunculan akun Instagram @kemenkominfo pada search engine juga membantu dan memudahkan masyarakat dalam mengakses akun. Non-follower @kemenkominfo yang juga mengikuti perkembangan informasi mengenai Covid19 bernama Azura Fianda, menyatakan bahwa ia mengakses informasi yang terdapat pada Instagram ini dikarenakan search engine otomatis (Fianda, 2020).

Penyajian konten-konten mengenai Covid-19 oleh akun instagram @ kemenkominfo mendapatkan respon yang baik dari masyarakat. Instagram dinilai cukup efektif dalam menyebarkan berita atau informasi mengenai Covid-19, terlebih untuk target audiens milenial dan generasi $\mathrm{Z}$ yang cenderung menggunakan Instagram dibandingkan dengan platform lainnya.

$$
\begin{array}{ccc} 
& \text { Manfaat penggunaan } & \text { Instagram } \\
\text { dalam } & \text { menyampaikan } & \text { informasi }
\end{array}
$$
pemerintah, seperti bagaimana penanganan Covid-19 baik dari aspek pemulihan kesehatan maupun penanganan ekonomi dapat dilihat dari besarnya respon masyarakat melalui like, komen dan juga bagaimana masyarakat turut me-repost konten-konten dari akun Instagram @ kemenkominfo.

Untuk itu Kemenkominfo selalu menjaga kredibilitas setiap kontennya. 
Terlebih Kemenkominfo menjadi pusat berbagai informasi bagi masyarakat luas. Seperti dilansir infopublik.id, peran Kemenkominfo mayoritas melakukan sosialisasi kepada masyarakat, supaya mentaati protokol kesehatan dengan disiplin, dan menangkal hoax yang terjadi di masyarakat (Tri, 2020). Di era digital ini banyak sekali hoax, informasi tidak benar, dan kabar berita yang tidak jelas. Humas Kemenkominfo sebagai pengelola akun $@$ @emenkominfo melakukan recheck dan klarifikasi terlebih dahulu sebelum disajikan ke masyarakat melalui Instagram tersebut (Setu, 2020).

Pandemi Covid-19 yang terjadi di Indonesia merupakan kasus kesehatan, dan ini sebenarnya wilayah dari Kementerian Kesehatan RI, bukan ruang lingkup Kemenkominfo. Namun sejak Maret tahun 2020, Kemenkominfo diamanatkan untuk membantu untuk menyebarkan informasiinformasi dari pemerintah pusat. Selain itu berkolaborasi dengan Kemenkes, dan Badan Nasional Penanggulan Bencana (BNPB). Tugas utama ini sebagai bentuk goverment public relations Kemenkominfo (Bonita, 2020).

Berdasarkan pengamatan peneliti pada akun Instagram @kemenkominfo, konten yang diunggah merupakan elaborasi dari berbagai sumber, seperti berikut ini:

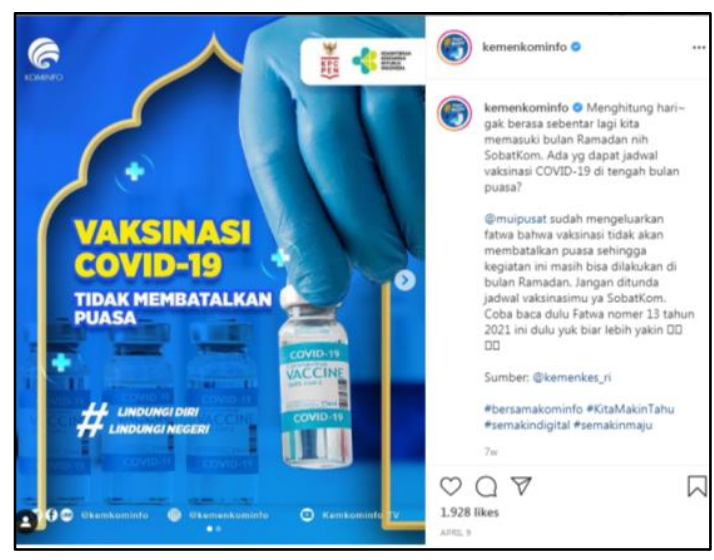

Gambar 6. Kolaborasi Konten Covid-19 (sumber: Instagram @ kemenkominfo, 2021)

Terlihat pada unggahan gambar 6, merupakan bentuk kolaborasi konten tentang penyuntikan vaksin tidak membatalkan orang yang sedang berpuasa. Selain gambar, terdapat narasi fatwa Majelis Ulama Indonesia di sebelah kanan, yang bersumber dari Kemenkes. Kemudian pada tampilan Instagram terlihat juga logo Kemenkominfo, Komite Penanganan Covid-19 dan Pemulihan Ekonomi Nasional (KPC PEN), dan Kementerian Kesehatan RI.

Setiap harinya akun @ kemenkominfo mengunggah setidaknya satu konten mengenai perkembangan dan informasi Covid-19. Hal ini membuat masyarakat merasa terpenuhi kebutuhan informasi mengenai Covid-19, ditambah 
dengan pengemasan informasi yang ringan dan mudah dipahami menjadi sangat efektif dan bermanfaat bagi penerima pesannya yaitu masyarakat pengguna instagram.

Tidak hanya gambar dan tulisan yang diunggah admin Kemenkominfo di Instagram, namun bentuk video juga disajikan di dalamnya. Menurut Lilis Sumiarsih sebagai ibu rumah tangga, pemahaman tentang seputar Covid-19 lebih dari enam puluh persen diperoleh dari Instagram Kemenkominfo, dan ia lebih intens melihat unggahan, jika kondisi sekitarnya dinilai mengkhawatirkan. Lilis menyukai bentuk konten video dari pada gambar dan tulisan. Hal ini bermanfaat bagi dirinya untuk mempratikan dengan mudah dan cepat tanggap (Sumiarsih, 2020).

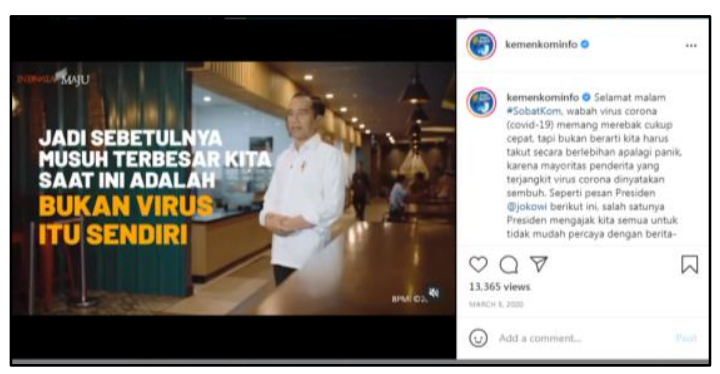

Gambar 7. Konten Video tentang Covid-19

(sumber: Instagram@kemenkominfo, 2021)

Salah satu video yang diunggah, seperti yang ditampilkan pada gambar 7 , terlihat Presiden Joko Widodo memberi penjelasan tentang musuh terbesar bukanlah virus itu sendiri, tapi rasa cemas, rasa panik, rasa ketakutan, dan berita-berita hoax. Pemahaman peneliti konten ini bertujuan untuk menenangkan masyarakat atas pandemi Covid-19 yang terjadi di Indonesia.

Akun@kemenkominfo tidak hanya ditujukan kepada orang dewasa, namun juga dtujukan kepada siapapun, termasuk generasi milenial dan generasi $\mathrm{Z}$. Pengamatan peneliti, konten yang diunggah tidak selalu formal atau serius, seperti yang dipersepsikan oleh masyarakat tentang lembaga pemerintah yang selalu formal. Konten yang diunggah ditujukan dan disesuaikan untuk followers milenial dan genersi Z. Konten mengenai Covid-19 dikemas dengan ringan, santai dan disisipi dengan humor yang sesuai dengan mereka, sebagai berikut:

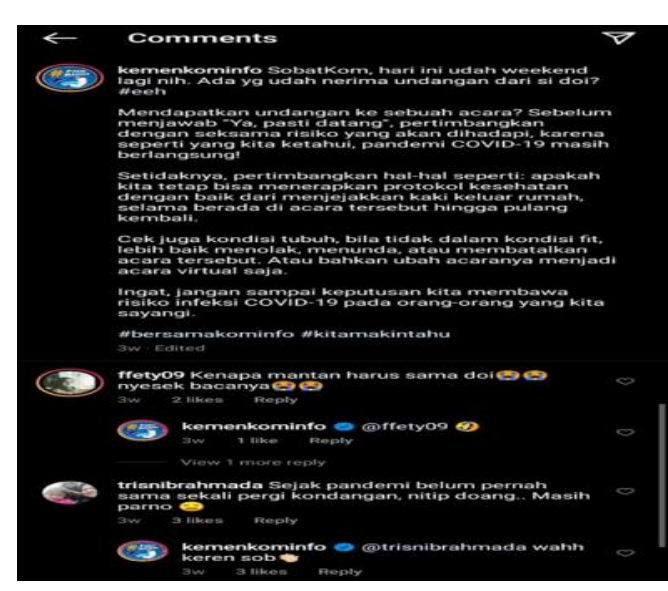

Gambar 8. Interaksi Kemenkominfo dengan Followers terkait informasi Covid-19 
(sumber: Instagram@kemenkominfo, 2021)

Unggahan konten pada gambar 8, mengenai protokol kesehatan saat pergi ke undangan pernikahan, disampaikan dengan gaya bahasa tidak formal. Kemudian followers mengomentari dengan gaya bahasa yang sama atau tidak formal. Interakasi sengaja diciptakan Kemenkominfo dengan pengguna Instagram, lewat konten yang disesuaikan kepada target follower yang diiginkan, yaitu milineal dan generasi Z. Selain komentar, pihak Kemenkominfo juga melakukan interaksi melalui direct message serta me-repost instastory followers maupun non-followers akun instagram @ kemenkominfo.

Instagram merupakan salah satu bentuk dari Computer Mediated Communication, dimana perilaku individu dapat dipertahankan atau diubah melalui pertukaran informasi. Kemenkominfo menggunakan Instagram sebagai media yang bertujuan untuk mensosialisasikan dan mengedukasi masyarakat tentang pandemi Covid-19 yang terjadi di Indonesia.

Dalam dimensi accessibility, penyebaran informasi yang disampaikan Kemenkominfo melalui akun Instagram @kemenkominfo memiliki daya jangkau yang luas karena jaringan internet yang tidak memiliki batasan. Hal ini mengakibatkan pihak internal maupun eksternal Kemenkominfo dapat mengakses akun Instagram @kemenkominfo dengan mudah kapanpun dan di manapun. Kendala jaringan internet terkadang terjadi, namun kondisi ini tidak menjadi hambatan yang berarti, karena sebagian besar dapat teratasi dalam waktu yang cukup singkat.

Dimensi speed dapat dipahami sebagai informasi yang disebarkan dalam waktu yang cepat dan direspon kembali dengan cepat oleh penerima pesan. Masyarakat yang mengikuti perkembangan pemberitaan Covid-19 melalui akun Instagram @kemenkominfo dapat langsung merespon konten dengan like, comment, share, saved, instastory dan direct message.

Dimensi amount, dilihat dari jumlah informasi yang diunggah pihak Kemenkominfo melalui Instagram resmi @kemenkominfo, di mana pihak Kemenkominfo mengunggah rutin minimal satu konten mengenai Covid-19 setiap harinya. Pihak eksternal mengakui bahwa informasi mengenai Covid-19 tercukupi.

Selanjutnya, pada dimensi cognitive effectiveness, informasi yang yang efektif 
dari Kemenkominfo dirasakan oleh masyarakat pengguna instagram, baik follower maupun non-follower akun instagram @kemenkominfo. Selain itu, dengan hadirnya akun instagram @ kemenkominfo di search engine instagram secara otomatis, makin mempermudah pengguna instagram untuk mengakses akun dan mendapatkan informasi terbaru seputar Covid-19.

Platform instagram juga menjadi

pilihan utama Kemenkominfo dalam menyebarkan informasi seputar Covid-19 kepada masyarakat karena dianggap menjadi platform yang efektif dalam penyebaran informasi serta memiliki followers paling banyak dibandingkan dengan platform media sosial resmi Kementerian Kominfo lainnya.

Dimensi relevance, dipahami sebagai kesesuaian informasi yang dilihat dari kebutuhan informasi masyarakat, dan apa yang diinformasikan pihak Kemenkominfo melalui akun Instagram @kemenkominfo yang sudah sesuai dan memenuhi kebutuhan masyarakat mengenai informasi Covid-19.

Dimensi motivating, menurut Kemenkominfo berupa unggahan mengenai Covid-19 di akun Instagram @ kemenkominfo yang berdampak bagi penerima pesan. Konten yang didistribusikan melalui Instagram untuk memberikan informasi dan sebagai media komunikasi, menyebabkan kebutuhan informasi yang dibutuhkan masyarakat terpenuhi. Konten ini juga menjadi anjuran dan motivasi untuk mematuhi protokol kesehatan. Masyarakat menjadi mengerti dan memilah informasi yang dapat dipertanggugjawabkan karena berasal dari akun resmi Instagram @ kemenkominfo.

Keenam dimensi CMC saling terkait satu sama lain dan saling melengkapi sehingga kinerja akun instagram@kemenkominfo terus berkembang, dan dapat mengikuti atau mengimbangi kebutuhan informasi masyarakat. Hal ini juga didukung oleh visualisasi, tatanan bahasa, kemasan informasi yang interaktif dan kreatif. Instagram dengan sajian fitur di dalamnya memungkinkan terjadinya interaksi antara pemerintah dan masyarakat.

Pada masa pandemi Covid-19 seperti ini, Instagram menjadi media komunikasi menjembatani komunikasi antara Kemenkominfo dengan masyarakat Indonesia. Berkurangnya aktivitas masyarakat di luar rumah selama masa pandemi, membuat hampir seluruh sektor menggunakan sistem digital dan online. 
Salah satu upaya pemerintah untuk tetap terkoneksi dengan masyarakat adalah melalui Instagram @kemenkominfo untuk memberikan informasi, himbauan dan aturan terkait Covid-19 kepada masyarakat.

\section{PENUTUP}

\section{Kesimpulan}

Berdasarkan analisis dan pembahasan, dapat disimpulkan bahwa penggunaan Instagram resmi @ kemenkominfo yang dikelola oleh Kemenkominfo sejak masa pandemi Covid-19 dipahami sebagai media komunikasi antara pemerintah dan masyarakat. Hadirnya akun Instagram @ kemenkominfo di search engine Instagram secara otomatis, mempermudah masyarakat dalam mengakses serta merespon informasi mengenai Covid-19 dengan mudah, cepat, dimanapun dan kapanpun secara online.

Instagram menjadi media yang mudah diakses oleh masyarakat dalam memenuhi kebutuhan informasi seputar Covid-19. Interaksi antara pemerintah dan masyarakat juga tercipta melalui fitur-fitur yang disajikan oleh media yang diperantarai oleh internet ini. informasi yang disampaikan dan yang dibutuhkan masyarakat mengenai Covid-19 sudah terpenuhi melalui akun Instagram @kemenkominfo. Akun@kemenkominfo memberi dampak yang baik bagi masyarakat untuk semakin menaati aturan dan termotivasi di masa pandemi Covid-19 saat ini.

Analisis jangkauan, kecepatan, dan jumlah informasi pada distribusi konten @kemenkominfo, dipahami dapat memberikan pengetahuan dan informasi sesuai kebutuhan masyarakat. Kemenkominfo melalui Instagram berupaya memberikan pemahaman dan arahan terkait Covid-19 kepada masyarakat Indonesia. Analisis ini mengacu pada landasan keenam dimensi dalam CMC sebagai proses komunikasi yang bersifat virtual dengan pemanfaatan perkembangan teknologi media komunikasi.

Kemenkominfo memberikan layanan dan penyebaran informasi terkait Covid-19 melalui akun resmi yang dikelola oleh Humas Kemenkominfo. Peran sebagai komunikator dan mediator atas merebaknya penyebaran Covid-19 di Indonesia, merupakan aplikasi konsep GPR Kemenkominfo di masa pandemi. Kemenkominfo berupaya membangun iklim komunikasi yang kondusif dengan masyarakat Indonesia melalui akun resmi Instagram @kemenkominfo. 


\section{Saran}

Pemahaman mengenai penggunaan Instagram@kemenkominfo sebagai media interaksi antara pemerintah dan masyarakat di masa pandemi, diketahui dapat mewakili fungsi aparatur sebagai komunikator dan mediator. Media baru diketahui sebagai wadah komunikasi yang dapat mewakili kredibilitas pemerintah dalam mengelola informasi yang dibutuhkan masyarakat.

$$
\text { Pendekatan kualitatif dalam }
$$

penelitian ini menggali aplikasi konsep Humas Pemerintah atau Government Public Relations, pada tataran produksi dan pengelolaan pesan dalam konten Instagram sebagai akun resmi Kemenkominfo. Penelitian menggunakan pendekatan kuantitatif disarankan dapat ditindaklanjuti pada kajian selanjutnya, untuk mengetahui efektivitas penggunaan Instagram terkait Covid-19 bagi masyarakat. Tujuannya, untuk mengetahui seberapa besar pengaruh penggunaan media sosial Instagram terhadap kebutuhan informasi, sosialisasi dan edukasi, terkait Covid-19 bagi masyarakat Indonesia di masa pandemi.

\section{DAFTAR PUSTAKA}

Bonita, A. (2020). Personal Interview Sub Koordinator Media Online Biro
Humas dan Pranata Humas Ahli Muda Kementerian Komunikasi dan Informatika RI.

Creswell, J. W. (2010). Research design pendekatan kualitatif, kuantitatif, dan mixed. Yogyakarta: Pustaka Pelajar.

Darmawan, D. (2012). Pendidikan teknologi informasi dan komunikasi: teori dan aplikasi. PT Remaja Rosdakarya.

Detikcom, T. (2020, September 2). Timeline Setengah Tahun COVID-19 di Indonesia. 1-5. https://new s.detik.com/berita/d5156199/timeline-setengah-tahuncovid-19-di-indonesia/

Fianda, A. (2020). Personal Interview non-follower Akun Instagram @kemenkominfo.

Kencana, W. H. (2020). Peran dan Manfaat Komunikasi Pembangunan pada Aplikasi Pelacak Covid-19 sebagai Media Komunikasi Kesehatan. Commed: Jurnal Komunikasi Dan Media, 5(1), 83-95.

Lister, M., Dovey, J., Giddings, S., Grant, I., \& Kelly, K. (2009). New Media: a critical introduction 2nd Edition. 
Mukhtar, P. D., \& Pd, M. (2013). Metode Praktis Penelitian Deskriptif Kualitatif. Jakarta: GP Press Group.

Mustafa, I. (2020, June 14). Pengguna Instagram di Indonesia Didominasi Wanita dan Generasi Milenial. https://www.good newsfromindonesia. id/2020/06/14/pengguna-instagramdi-ind onesia-didominasi-wanita-dangenerasi-milenial

Nasrullah, R. (2015). Media sosial: Perspektif komunikasi, budaya, dan sosioteknologi. Bandung: Simbiosa Rekatama Media, 2016, 2017.

Prakasa, R. (2020). Personal Interview follower Akun Instagram @kemenkominfo.

Rorong, M. J. (2019). Penempatan Teori Dalam Ilmu Komunikasi. Commed: Jurnal Komunikasi Dan Media, 4(1), 90-107.

Rubiyanto, \& Yuliani, D. T. (2020). Pengaruh Penggunaan Instagram terhadap Pembentukan Citra CNN Indonesia bagi Followers. Promedia (Public Relation Dan Media Komunikasi), 6(2). relations dan media komunikasi. Jakarta: Rajawali Pers, 134.

Setu, F. (2020). Personal Interview Plt. Kepala Biro Humas Kementerian Komunikasi dan Informatika RI.

Situmeang, I. R. (2020). Konstruksi Komodifikasi Media Komunikasi untuk Kampanye Kesehatan di Instagram dalam Pencegahan Virus Corona Pada New Era Masyarakat 5.0. Commed: Jurnal Komunikasi Dan Media, 5(1), 34-53.

Solomon, M. R. (2011). Consumer Behavior: buying having, and being 9th Ed New Jersey. USA: Pearson Prentice Hall.

Sumiarsih, L. (2020). Personal Interview follower Akun Instagram @kemenkominfo.

Tri, A. (2020, October 20). Tiga Peran Menonjol Kominfo Selama Satu Tahun. https://infopublik.id/kategori/nasional -ekonomi-bisnis/488071/tiga-peranmenonjol-kominfo-selama-satu-tahun

Ruslan, R. (2010). Manajemen public 